\title{
Can fatigue predict walking capacity of patients with Parkinson's disease?
}

\author{
A fadiga pode predizer a mobilidade e a capacidade de marcha em pacientes com doença \\ de Parkinson?
}

Davi Vilela CARVALHO', Renata Maria Silva SANTOS², Helen Cardoso de MAGALHÃES ${ }^{3}$, Mariana Soares de SOUZA4, Paulo Pereira CHRISTO4${ }^{4}$, Camila Megale de ALMEIDA-LEITE ${ }^{5}$, Paula Luciana SCALZO5

\begin{abstract}
Although fatigue is an expressive symptom of Parkinson's disease (PD), few studies have investigated the association between fatigue, mobility and walking capacity of these patients. Objective: To investigate whether fatigue is an independent factor associated with mobility and the walking capacity in patients with PD. Methods: Forty-eight patients with PD (22 with fatigue) were tested for mobility and their walking capacity: Timed Up and Go (TUG), 10-Meter Walk Test (10MWT) at usual and fastest speed, and 6-Minute Walk Test (6MWT). Fatigue was measured with Parkinson's Fatigue Scale (PFS-16). Linear regression analysis was used to investigate if fatigue is an independent factor contributing to variance in mobility and walking capacity. Results: There was a positive correlation between PFS-16 and TUG $\left(r_{s}=0.385\right.$; $p=0.007)$. There was a negative correlation between PFS-16 and 10MWT at comfortable $(r=-0.385 ; p=0.007)$ and fast speeds $(r=-0.396$; $p=0.005)$, and 6MWT ( $r=-0.472 ; p=0.001)$. Linear regression analysis revealed that fatigue did not explain the variance of TUG and $10 M W T$. PFS-16, age and section III of UPDRS explained 49.6\% (adjusted $\mathrm{R}^{2} ; \mathrm{p}<0.001$ ) variance in the 6MWT, and fatigue was the most significant predictor ( $F=-32.1 ; p=0.022$ ). Conclusions: Fatigue is an independent factor contributing to the distance covered during $6 \mathrm{MWT}$ in patients with PD. Our results highlight the importance of recognition and management of this symptom.
\end{abstract}

Keywords: Parkinson's disease; fatigue; mobility; gait speed; walking capacity.

\section{RESUMO}

Embora a fadiga seja um sintoma importante na doença de Parkinson (DP), poucos estudos investigaram a associação entre fadiga, mobilidade e capacidade de marcha nesses pacientes. Objetivo: Investigar se a fadiga é um fator independente associado à mobilidade e à capacidade de marcha em pacientes com DP. Métodos: Quarenta e oito pacientes com DP (22 com fadiga) foram avaliados com testes de mobilidade e capacidade de marcha: Timed Up and Go (TUG), Teste de Caminhada de 10 metros (T10m) na velocidade usual e máxima, Teste de Caminhada de Seis Minutos (TC6m). A fadiga foi medida pela Escala de Fadiga no Parkinson (PFS-16). A análise de regressão linear foi utilizada para investigar se a fadiga é um fator independente que contribui para a variação na mobilidade e capacidade de marcha. Resultados: Houve correlação positiva entre PFS-16 e TUG ( $r s=0,385 ; p=0,007$ ). Houve correlação negativa entre PFS-16 e T10m na velocidade usual $(r=-0,385 ; p=0,007)$ e máxima $(r=-0,396 ; p=0,005)$ e TC6m $(r=-0,472 ; p=0,001)$. Análise de regressão linear revelou que a fadiga não explicava a variância do TUG e T10m. A PFS-16, a idade e a seção III da UPDRS explicaram 49,6\% (R2 ajustado, p<0,001) da variância no TC6m e a fadiga foi o preditor mais significativo ( $F=-32,1 ; p=0,022)$. Conclusões: A fadiga é um fator independente que contribui para a distância percorrida durante o TC6 m em pacientes com DP. Nossos resultados destacam a importância do reconhecimento e manejo desse sintoma.

Palavras-chave: doença de Parkinson; fadiga; mobilidade; velocidade de marcha; capacidade de marcha.

\footnotetext{
'Universidade Federal de Minas Gerais, Programa de Pós-Graduação em Neurociências, Belo Horizonte MG, Brazil.

${ }^{2}$ Universidade Federal de Minas Gerais, Programa de Pós-Graduação em Patologia, Belo Horizonte MG, Brazil.

${ }^{3}$ Universidade Federal de Minas Gerais, Instituto de Ciências Biológicas, Belo Horizonte MG, Brazil.

4Santa Casa de Belo Horizonte, Centro de Especialidades Médicas, Belo Horizonte MG, Brazil.

5Instituto de Ciências Biológicas, Departamento de Morfologia, Belo Horizonte MG, Brazil.

Davi Vilela CARVALHO (ID https://orcid.org/0000-0002-7994-8325; Renata Maria Silva SANTOS (iD) https://orcid.org/0000-0001-5737-7712; Helen Cardoso de MAGALHÃES (iD https://orcid.org/0000-0003-0582-305X; Mariana Soares de SOUZA iD https://orcid.org/0000-0002-5301-003X; Paulo Pereira CHRISTO (ID) https://orcid.org/0000-0003-1224-5243; Camila Megale de ALMEIDA-LEITE (iD) https://orcid.org/0000-0003-2694-8521; Paula Luciana SCALZO (iD) https://orcid.org/0000-0003-1383-8550
}

Correspondence: Paula Luciana Scalzo; Departamento de Morfologia, Instituto de Ciências Biológicas; Avenida Antônio Carlos, 6627; 31270-901 Belo Horizonte MG, Brazil; E-mail: paula@icb.ufmg.br

Conflict of interest: The authors declare no conflict of interest.

Received 24 April 2019; Received in final form 30 July 2019; Accepted 09 September 2019. 
Parkinson's disease (PD)-related fatigue is one of the most common and disabling symptoms and affects approximately $50 \%$ of PD patients ${ }^{1,2}$. Patients report a significant reduction in energy levels or perception of increased efforts to perform daily activities. However, this symptom is distinct from sleepiness, lack of motivation, and depression. To be considered as a relevant symptom, it must be present for most of the day or nearly every day during the previous month ${ }^{3}$.

Fatigue occurs since early stages of $\mathrm{PD}$, including the pre-motor period, to more advanced stages of the disease ${ }^{4}$. Studies have shown that fatigue is correlated to other symptoms, such as depression, anxiety, and sleep disturbance ${ }^{5-8}$. The pathophysiology of fatigue has not been elucidated yet; however, increased circulating inflammatory cytokines, such as interleukin 6 (IL-6) may play a significant role ${ }^{9}$. Dysfunction in nigrostriatal and extrastriatal dopaminergic or non-dopaminergic pathways, and autonomic nerve system impairment are proposed as pathophysiological mechanisms of fatigue ${ }^{4}$.

PD fatigue can be divided into peripheral and central. Peripheral fatigue occurs after repeated muscle contractions, involves decreased muscle strength and can be measured ${ }^{10}$. Peripheral fatigue is produced by changes in neuromuscular transmission, neuromuscular junctions, muscle cell membranes and factors within muscle fibers ${ }^{11}$. On the other hand, central or subjective fatigue can be further divided into physical and mental ${ }^{10,12}$. The effort to perform activities that depend on skeletal muscles to generate force and cognitive demands are reported in physical and mental fatigues, respectively ${ }^{10,12}$. Central fatigue is more often assessed using one or multidimensional questionnaires ${ }^{13}$. Parkinson Fatigue Scale (PFS-16) is designed to measure the physical aspects of subjective fatigue and its impact on daily activities, but it does not consider cognitive or emotional features ${ }^{5,13}$.

Although fatigue is an important symptom in PD, only few studies have assessed its association with mobility, walking capacity, and physical activity in patients with $\mathrm{PD}^{14-18}$. Some studies have shown an association between fatigue severity and self-reported leisure activity, frequency of vigorous physical activity, and time spent moving ${ }^{14}$. A 12 -week prospective cohort study presented a significant association between fatigue and dynamic activities ${ }^{15}$. Patients who experience higher levels of fatigue are less physically active in their daily lives ${ }^{15}$. Nonetheless, this symptom was not able to predict the level of physical activity in two proposed models by Lana, although fatigue was correlated with Human Activity Profile scores ${ }^{16}$. Physical activity, physical function, psychological well-being, and quality of life were reduced in PD patients with greater subjective fatigue ${ }^{6-8}$. Recently, Kader et al. showed that fatigue is the third strongest factor that independently contributes to perceived walking difficulties in people with PD, after freezing of gait and general self-effi$\mathrm{cacy}^{18}$. This study aimed to investigate whether fatigue can predict mobility and walking capacity of patients with PD.

\section{METHODS}

The Research Ethics Committee of Universidade Federal de Minas Gerais, Brazil, approved the design of the cross-sectional study. Participants were recruited from the movement disorders outpatient clinic of Santa Casa Hospital, Belo Horizonte City, Brazil. Written informed consent was obtained from all subjects before their participation.

Forty-eight patients with PD diagnosis according to the United Kingdom Brain Bank Criteria were included ${ }^{19}$. Patients with cognitive dysfunction were excluded, according to the Mini-Mental State Examination (MMSE) adapted for the Brazilian elderly population ${ }^{20}$, or with any other medical disorder that could potentially be associated with fatigue, such as heart and pulmonary diseases, renal and hepatic failure, or cancer. Only those subjects with a sedentary lifestyle with no regular exercises were recruited to avoid the confounding factor of physical activity levels.

Demographic data, medical history, and pharmacological treatment (disease duration, antiparkinsonian medication, and other treatment) were collected in a structured interview. L-dopa equivalent dose (LED) was calculated for each studied patient ${ }^{21}$.

All patients were evaluated with the Unified Parkinson's Disease Rating Scale (UPDRS), which assesses different signs and symptoms of $\mathrm{PD}^{22}$. PD patients were tested during a clinical "on" status, with the more severe side being tested. The "tremor score" and the "non-tremor score" for each patient were calculated according to Lewis et al. ${ }^{23}$. The patients were classified: tremor-dominant type, akineticrigid or mixed type. The modified Hoehn and Yahr (HY) staging scale was used to establish the stage of $\mathrm{PD}^{24}$, which ranges from stage I (unilateral involvement) to stage V (confinement to bed or wheelchair, unless aided). The modified Schwab and England activities of the daily living scale was used to assess daily routines.

The timed up and go test (TUG) was used to evaluate gait in a functional situation of their daily lives. It is a simple, quick and widely used clinical performance-based measure of balance and mobility. Walking aids were used, patients were asked to stand up from a standard chair, walk 3 meters at the easy and fast-paced, turn 180 degrees, walk back to the chair and sit down. The time to complete the task was measured with a stopwatch. Timing starts with the 'go' command and stops when the patient's back is positioned against the back of the chair after sitting down. The time taken to complete is recorded in seconds ${ }^{25,26}$.

Comfortable and fast gait speeds were assessed using the 10-Meter Walk Test (10MWT), which was performed on a flat 14-meter corridor and the time required to cover the 10 intermediate meters was registered with a digital stopwatch. The first 2 meters were provided to reach the patient's usual gait speed and the last 2 meters to slow down and stop. This test was applied 2 times and the average value was 
calculated. This test is a measure of overall walking performance but does not include an endurance component ${ }^{26}$.

The 6-Minute Walk Test (6MWT) was used to measure the maximal distance that the patient can walk on a flat surface, as fast as possible, for 6 minutes. Patients were allowed to self-pace and rest as needed while they walked back and forth along a marked walkway. For some patients, it is a submaximal test of aerobic capacity ${ }^{26}$.

Fatigue was assessed with the PFS-16, which is a selfreport questionnaire of 16 statements regarding fatigue in which patients choose how much they agree or disagree with these statements. In this study, a cut-off point of 3.3 was used to identify patients with PD who perceive fatigue as a problem. Higher scores indicated more severe fatigue ${ }^{5}$.

The categorical variables are described by the number of participants (percentage). Demographic and clinical features were described using mean and standard deviation or median and range (min, max). Pearson (r) or Spearman (rs) correlations were used to assess the association between the independent variable ( fatigue) and mobility and walking capacity.
A linear regression analysis was used to exclude confounding factors (age, cognitive function, UPDRS II and III, and HY stage). The significance level applied was $<0.05$. All statistical analyses were performed with the SPSS Windows (SPSS Inc, Chicago, IL, USA).

\section{RESULTS}

A total of 101 patients were contacted, but 34 (33.7\%) were not eligible due to the exclusion criteria, 11 (10.9\%) declined to participate, and $8(7.9 \%)$ patients did not attend the appointments or did not show PD drug effects. Therefore, the final sample consisted of 48 (of which 52.5\% were men) participants. Three (6.3\%), one (2.1\%), 17 (35.4\%), eight (16.7\%) and 19 (39.7\%) individuals were classified as stage 1, 1.5, 2, 2.5, and 3 according to the modified HY scale, respectively. Furthermore, 22 (45.8\%) participants showed significant fatigue. Demographic and clinical features are shown in Table 1.

Table 1. Demographic and clinical characteristics of study population $(n=48)$.

\begin{tabular}{|c|c|c|c|c|}
\hline Variables & Participants $(n=48)$ & $\begin{array}{l}\text { Patients without } \\
\text { fatigue }(n=26)\end{array}$ & $\begin{array}{l}\text { Patients with fatigue } \\
\qquad(n=22)\end{array}$ & $\mathrm{p}$-value \\
\hline Gender (men), n (\%) & $27(52.5 \%)$ & $15(57.7 \%)$ & $12(46.2 \%)$ & $0.529 *$ \\
\hline Age (years), mean (SD) & $67.2(10.0)$ & $64.1(7.1)$ & $70.9(11.8)$ & 0.025 \\
\hline $\begin{array}{l}\text { Education level (years), } \\
\text { mean (SD) }\end{array}$ & $8.3(4.8)$ & $9.3(5.1)$ & $7.1(4.4)$ & 0.114 \\
\hline $\begin{array}{l}\text { MMSE (scores), } \\
\text { mean (SD) }\end{array}$ & $23.5(4.4)$ & $25.3(3.6)$ & $21.3(4.3)$ & 0.001 \\
\hline $\begin{array}{l}\text { Onset of symptoms } \\
\text { (years), mean (SD) }\end{array}$ & $9.0(5.3)$ & $8.4(3.9)$ & $9.8(6.6)$ & 0.353 \\
\hline $\begin{array}{l}\text { Disease duration } \\
\text { (years), mean (SD) }\end{array}$ & $7.4(4.6)$ & $7.1(3.9)$ & $7.7(5.4)$ & 0.641 \\
\hline $\begin{array}{l}\text { LEDD — Levodopa (mg), } \\
\text { mean (SD) }\end{array}$ & $706.1(308.1)$ & $592.3(269.7)$ & $725.0(255.2)$ & 0.098 \\
\hline $\begin{array}{l}\text { UPDRS, mean (SD) } \\
\text { UPDRS I score } \\
\text { UPDRS II score } \\
\text { UPDRS III score } \\
\text { UPDRS total score }\end{array}$ & $\begin{array}{l}3.0(2.4) \\
15.7(6.0) \\
27.0(11.9) \\
45.7(17.3)\end{array}$ & $\begin{array}{c}2.5(1.9) \\
13.5(5.8) \\
22.4(10.2) \\
38.4(14.9)\end{array}$ & $\begin{array}{c}3.6(2.8) \\
18.2(5.2) \\
32.6(11.5) \\
54.4(16.2)\end{array}$ & $\begin{array}{l}0.093 \\
0.006 \\
0.002 \\
0.001\end{array}$ \\
\hline $\begin{array}{l}\text { Phenotype } \\
\text { Tremor, n (\%) } \\
\text { Rigidic-ackinetic, n (\%) } \\
\text { Mixed, n (\%) }\end{array}$ & $\begin{array}{c}2(4.2 \%) \\
23(47.9 \%) \\
23(47.9 \%)\end{array}$ & $\begin{array}{c}1(3.85 \%) \\
11(42.3 \%) \\
14(53.85 \%)\end{array}$ & $\begin{array}{c}1(4.55 \%) \\
12(54.55 \%) \\
9(40.9 \%)\end{array}$ & $0.669 *$ \\
\hline $\begin{array}{l}\text { Hoehn and Yahr } \\
\text { staging (scores), } \\
\text { median (min-max) }\end{array}$ & $\begin{array}{c}2.5 \\
(1.0-3.0)\end{array}$ & $\begin{array}{c}2.0 \\
(1.0-3.0)\end{array}$ & $\begin{array}{c}3.0 \\
(2.0-3.0)\end{array}$ & $0.025^{\&}$ \\
\hline $\begin{array}{l}\text { Schawb and England } \\
\text { (scores), } \\
\text { median (min-max) }\end{array}$ & $\begin{array}{c}70 \% \\
(50-100)\end{array}$ & $\begin{array}{c}80 \% \\
(70-100)\end{array}$ & $\begin{array}{c}70 \% \\
(50-80)\end{array}$ & $0.008^{\&}$ \\
\hline
\end{tabular}


Table 1. Continuation.

\begin{tabular}{|c|c|c|c|c|}
\hline Variables & Participants $(n=48)$ & $\begin{array}{l}\text { Patients without } \\
\text { fatigue }(n=26)\end{array}$ & $\begin{array}{l}\text { Patients with fatigue } \\
\qquad(n=22)\end{array}$ & $\mathrm{p}$-value \\
\hline $\begin{array}{l}\text { TUG (s), } \\
\text { median (min-max) } \\
\text { Patients }>16 \mathrm{~s}, \mathrm{n}(\%)\end{array}$ & $\begin{array}{c}13.3 \\
(7.1-97.0) \\
15(31.2 \%)\end{array}$ & $\begin{array}{c}11.9 \\
(7.1-20.5) \\
3(11.5)\end{array}$ & $\begin{array}{c}17.5 \\
(8.4-97.0) \\
12(54.5 \%)\end{array}$ & $0.009^{\&}$ \\
\hline $\begin{array}{l}\text { 10MWT (comfortable } \\
\text { speed) (m/s), mean (SD) }\end{array}$ & $0.94(0.29)$ & $1.05(0.19)$ & $0.80(0.34)$ & 0.004 \\
\hline $\begin{array}{l}\text { 10MWT (maximal } \\
\text { speed) (m/s), mean (SD) }\end{array}$ & $1.22(0.38)$ & $1.37(0.30)$ & $1.04(0.39)$ & 0.002 \\
\hline $\begin{array}{l}\text { 6MWT (meters), } \\
\text { mean (SD) }\end{array}$ & $359.0(124.4)$ & $418.6(89.1)$ & $288.5(124.8)$ & $<0.001$ \\
\hline $\begin{array}{l}\text { PFS-16 (scores), } \\
\text { mean (SD) }\end{array}$ & $3.2(1.0)$ & $2.4(0.57)$ & $4.2(0.48)$ & $<0.001$ \\
\hline
\end{tabular}

MMSE: Mini-Mental State Examination; UPDRS: Unified Parkinson's Disease Rating Scale; HY: Hoehn and Yahr Staging of Parkinson's disease; SE: Schawb and England Activities of Daily Living; 10MWT: 10-Meter Walk Test;TUG:Timed Up and Go; 6MWT: 6-Minute Walk Test; PFS-16: Parkinson's Disease Fatigue Scale.

*Chi-square test. ${ }^{\star M a n n}$-Whitney U test. Student's t-test to other variables.

Patients with fatigue were older and had worse cognitive functions when compared to patients without fatigue. They had higher scores on UPDRS (II, III and total UPDRS scores) and more advanced stages of the disease, besides higher levels of functional dependence according to SE scale. This group spent more time in TUG. Comfortable and maximum gait speeds and distance covered during 6MWT were smaller in fatigue group.

Bivariate correlations between PFS-16 score and TUG, 10MWT, and 6MWT are shown in Table 2. The degree of fatigue was correlated with mobility and the walking capacity. Linear regression analysis revealed that age, PD symptoms (UPDRS III), and severity of fatigue (PFS-16) were independent contributors to $6 \mathrm{MWT}$, and explained $49.6 \%$ of total variance of 6MWT (Table 3). Fatigue did not explain total variance of TUG and 10MWT (comfortable and fast gait speeds). In the first dependent variable (TUG), the model included age and severity of PD symptoms (UPDRS III) and explained $38.75 \%$ of total variance of TUG. For the second dependent variable (10MWT), the model included age and cognitive function (MMSE) and explained 35.9 and $41.2 \%$ of total variance of comfortable and fast gait speeds, respectively.

\section{DISCUSSION}

Frequency of fatigue (46\%) observed here is consistent with those found in the literature (50\%) for PD patients. ${ }^{27}$. Few studies investigated the impact of fatigue on mobility and walking capacity in individuals with $\mathrm{PD}^{11,28,29}$. Our results showed that patients with higher scores of PFS16 had worse performance in a basic mobility skill (TUG), gait speed over a short distance (10MWT), and endurance and ability to walk over longer distances (6MWT). TUG test may be a useful tool
Table 2. Bivariate correlation between PFS-16 and mobility and exercise capacity.

\begin{tabular}{lcc}
\hline Variables & \multicolumn{2}{c}{ PFS-16 } \\
\hline \multicolumn{1}{c}{$r$} & p-value \\
\hline TUG* & 0.385 & 0.007 \\
\hline 10MWT (comfortable speed) & -0.385 & 0.007 \\
10MWT (maximal speed) & -0.396 & 0.005 \\
\hline 6MWT & -0.472 & 0.001 \\
\hline
\end{tabular}

TUG:Timed Up and Go; 10MWT: 10-Meter Walk Test; 6MWT: 6-Minute Walk Test; PFS-16: Parkinson's Disease Fatigue Scale. *Spearman's rank correlation coefficient. Pearson correlation coefficient to other variables.

Table 3. Linear regression.

\begin{tabular}{lccc}
\hline Variables & \multicolumn{3}{c}{$6 \mathrm{MWT}$} \\
\hline $\begin{array}{c}\text { Beta } \\
\text { (p-value) }\end{array}$ & p-value & $\begin{array}{c}95 \% \text { confidence } \\
\text { interval }\end{array}$ \\
\hline Age & -4.4 & 0.002 & $-7.1 /-1.7$ \\
\hline UPDRS III & -4.1 & 0.001 & $-6.5 /-1.7$ \\
\hline PFS-16 & -32.1 & 0.022 & $-59.4 /-4.8$ \\
\hline R $^{2}$ adjusted & & $49.6 \%$ & \\
\hline
\end{tabular}

6MWT: 6-Minute Walk Test; UPDRS: Unified Parkinson's Disease Rating Scale; PFS-16: Parkinson's Disease Fatigue Scale.

to assess patients with PD, because they normally exhibit difficulty in performing activities, such as walking and turning, and complex or dual tasks ${ }^{25,26}$. In elderly people, it is considered normal to spend $\leq 10 \mathrm{~s}$ in the $\mathrm{TUG}^{25}$. For PD, patients who spend more than 16 seconds to complete the TUG have an increased risk of falling ${ }^{30}$. In our study, $31.2 \%$ patients spent 
more than 16 seconds to perform this test. The 10MWT and 6MWT are common clinical gait assessment tools. The first test measures average gait speed at a single pace (i.e. comfortable or fast) over a short distance. In contrast, 6MWT measures their walking endurance at a self-determined pace over a long distance ${ }^{25,26}$. Our study showed that mean gait speed was $0.94 \mathrm{~m} / \mathrm{s}$ in PD patients. This result corroborates findings of a previous study conducted by Paker et al. ${ }^{31}$. According to the literature, the gait speed is between 0.18 and $1.21 \mathrm{~m} / \mathrm{s}$ in $\mathrm{PD}$ patients. These values are much lower when considering the elderly patients who reach a speed of $1.30-1.36 \mathrm{~m} / \mathrm{s}^{28,31}$.

After linear regression analysis, considering fatigue as an independent variable, it did not explain the variance of reaction time (TUG) and gait speed (T10M). However, PFS-16, age, and section III of UPDRS explained variance in 6MWT and fatigue was the most significant predictor of 6MWT. This could be an important factor to increase patient's physical inactivity. In previous studies, associations between gait impairment and activity limitation in PD were described ${ }^{31,32}$. From a clinical perspective, our results suggest that fatigue may reduce functionality in everyday activities of PD patients and prolong periods of sedentary behaviors. This is particularly important seen that PD-related fatigue is one of the most common and disabling symptoms in these patients ${ }^{2,3}$.

The study by Kader et al. found eight contributing factors for the perception of gait difficulty in individuals with PD: freezing, general self-efficacy, fatigue, PD duration, low limb function, orthostatic hypotension, bradykinesia, and instability postural ${ }^{18}$. Fatigue was the third strongest related factor. Those findings are in accordance to results found here, considering that fatigue is an independent factor that contributes to the perception of walking difficulty ${ }^{18}$. Santos et al. analyzed the effect of fatigue in lower limbs on gait parameters. They found that fatigue caused adjustments in gait parameters, and these adjustments were interpreted as adaptation strategies to maintain balance in response to the provoked fatigue $^{28}$. Although the study also observed that level of a physical activity of individuals with and without PD did not affect gait performance after provoked fatigue, practice of physical activity is fundamental to improve gait of individuals with PD.

Fatigue has been linked to mobility and walking and aerobic abilities in people with multiple sclerosis and mild neurological disability ${ }^{33}$. These authors suggested that a better understanding of fatigue could lead to more effective management of this highly disabling symptom ${ }^{32,33}$. Nevertheless, according to Hoang et al., fatigue was not associated with physical parameters, including 10MWT and 6MWT ${ }^{34}$.

An important point discussed in the literature is that mildly down-regulated thyroid function in elderly people may be protective and is associated to better physical function and lower mortality when compared with euthyroid individu$\mathrm{als}^{35}$. However, Vestergaard et al. showed that lower extremity function, walking speed, mobility, and instrumented activities of life are impairment for older people who report fatigue even after adjustment of their health behaviors, diseases, inflammatory markers, and thyroid function ${ }^{36}$.

A limitation of this study was that antidepressant medication intake and nonmotor symptoms (mainly affective and sleep disorders), which are known to influence PD patients ${ }^{29}$, could not be assessed. Moreover, the cross-sectional design of the study does not allow further exploration of causal relationship between studied variables. Hence, the result of this study should be interpreted within this context. The strength of the present study is that patients were investigated with validated instruments for PD and fatigue, and tests were mainly used to assess mobility and walking capacity of patients with PD. The findings of this study are important once fatigue is considered one of the most common and disabling nonmotor symptoms in PD patients and it harms their quality of life ${ }^{27}$.

\section{References}

1. Friedman J, Friedman H. Fatigue in Parkinson's disease. Neurology. 1993 Oct;43(10):2016-18. https://doi.org/10.1212/wnl.43.10.2016

2. Friedman JH, Brown RG, Comella C, Garber CE, Krupp LB, Lou JS, et al. Fatigue in Parkinson's disease: a review. Mov Disord. 2007 Feb;22(3):297-308. https://doi.org/10.1002/mds.21240

3. Kluger BM, Herlofson K, Chou KL, Lou JS, Goetz CG, Lang AE, et al. Parkinson's disease-related fatigue: a case definition and recommendations for clinical research. Mov Disord. 2016 May;31(5):625-31 https://doi.org/10.1002/mds.26511

4. Alves $\mathrm{G}$, Wentzel-Larsen T, Larsen JP. Is fatigue an independent and persistent symptom in patients with Parkinson's disease? Neurology. 2004 Nov;63(10):1908-11. https://doi.org/10.1212/01. wnl.0000144277.06917.cc

5. Kummer A, Scalzo P, Cardoso F, Teixeira AL. Evaluation of fatigue in Parkinson's disease using the Brazilian version of Parkinson's Fatigue Scale. Acta Neurol Scand. 2011 Feb;123(2):130-6. https://doi. org/10.1111/j.1600-0404.2010.01364.x van Hilten JJ, Weggeman M, van der Velde EA, Kerkhof GA, van DijkJG, Roos RA. Sleep, excessive daytime sleepiness and fatigue in Parkinson's disease.J Neural Transm Park Dis Dement Sect. 1993;5(3):235-44.

7. Valko PO, Waldvogel D, Weller M, Bassetti CL, Held U, Baumann CR. Fatigue and excessive daytime sleepiness in idiopathic Parkinson's disease differently correlate with motor symptoms, depression and dopaminergic treatment. Eur J Neurol. 2010 Dec;17(12):1428-36. https://doi.org/10.1111/j.1468-1331.2010.03063.x

8. Nicoletti A, Mostile G, Stocchi F, Abbruzzese G, Ceravolo R, Cortelli P, et al. Factors influencing psychological well-being in patients with Parkinson's disease. PLoS One. 2017 Dec;12(12):e0189682. https:// doi.org/10.1371/journal.pone.0189682

9. Pereira JR, Santos LVD, Santos RMS Campos ALF, Pimenta AL, de Oliveira MS, et al. IL-6 serum levels are elevated in Parkinson's disease patients with fatigue compared to patients without fatigue. J Neurol Sci. 2016 Nov;370:153-6. https://doi.org/10.1016/j. jns.2016.09.030 
10. Lou JS, Kearns G, Oken B, Sexton G, Nutt J. Exacerbated physical fatigue and mental fatigue in Parkinson's disease. Mov Disord. 2001 Mar;16(2):190-6. https://doi.org/10.1002/mds.1042

11. Huang YZ, Chang FY, Liu WC, Chuang YF, Chuang LL, Chang YJ. Fatigue and muscle strength involving walking speed in Parkinson's disease: insights for developing rehabilitation strategy for PD. Neural Plast. 2017;2017:1941980. https://doi.org/10.1155/2017/1941980

12. Garber CE, Friedman JH. Effects of fatigue on physical activity and function in patients with Parkinson's disease. Neurology. 2003;60(7):1119-24. https://doi.org/10.1212/01. wnl.0000055868.06222.ab

13. Friedman JH, Alves G, Hagell P, Marinus J, Marsh L, Martinez-Martin P, et al. Fatigue rating scales critique and recommendations by the movement disorders society task force on rating scales for Parkinson's disease. Mov Disord. 2010 May;25(7):805-22. https://doi.org/10.1002/mds.22989

14. Hoff J, van Hilten J, Middelkoop H, Roos R. Fatigue in Parkinson's disease is not associated with reduced physical activity. Parkinsonism Relat Disord. 1997;3(1):51-4.

15. Elbers R, van Wegen EE, Rochester L, Hetherington V, Nieuwboer A, Willems AM, et al. Is impact of fatigue an independent factor associated with physical activity in patients with idiopathic Parkinson's disease? Mov Disord. 2009 Jul;24(10):1512-8. https://doi. org/10.1002/mds.22664

16. Lana RC, Araújo LN, Cardoso F, Rodrigues-de-Paula F. Main determinants of physical activity levels in individuals with Parkinson's disease. Arq Neuropsiquiatr. 2016 Feb;74(2):112-6. http:// dx.doi.org/10.1590/0004-282X20160009

17. Christiansen CL, Schenkman ML, McFann K, Wolfe P, Kohrt WM. Walking economy in people with Parkinson's disease. Mov Disord. 2009 Jul;24(10):1481-7. https://doi.org/10.1002/mds.22621

18. Kader M, Ullén S, Iwarsson S, Odin P, Nilsson MH. Factors contributing to perceived walking difficulties in people with Parkinson's disease.J Parkinsonism Dis. 2017 May;7(2):397-407. https://doi.org/10.3233/JPD-161034

19. Hughes AJ, Daniel SE, Kilford L, Lees AJ. Accuracy of clinical diagnosis of idiopathic Parkinson's disease: a clinicopathological study of 100 cases. J Neurol Neurosurg Psychiatry. 1992;55(3):181-4. https://doi.org/10.1136/jnnp.55.3.181

20. Bertolucci PH, Brucki SM, Campacci SR, Juliano Y. The Mini-Mental State Examination in a general population: impact of education status. Arq Neuropsiquiatr. 1994 Mar;52(1):1-7. http://dx.doi. org/10.1590/S0004-282X1994000100001

21. Tomlinson CL, Stowe R, Patel S, Rick C, Gray R, Clarke CE. Systematic review of levodopa dose equivalency reporting in Parkinson's disease. Mov Disord. 2010 Nov;25(15):2649-53. https://doi.org/10.1002/mds.23429

22. Fahn S, Elton R. Members of the UPDRS Development Committee, Unified Parkinson's Disease Rating Scale. In: Fahn S, Marsden CD, Calne DB, Goldstein M (Editors). Recent developments in Parkinson's disease. Florham Park, NJ: Macmillan Health Care Information; 1967. v.2. p.153-63; 293-304

23. Lewis SJ, Foltynie T, Blackwell AD, Robbins TW, Owen AM, Barker RA. Heterogeneity of Parkinson's disease in the early clinical stages using a data driven approach. J Neurol Neurosurg Psychiatry. 2005 Mar;76:343-8. doi:10.1136/jnnp.2003.033530
24. Hoehn MM, Yahr MD. Parkinsonism: Onset, progression and mortality. Neurology. 1967 May;17(5):427-42. https://doi.org/10.1212/ wnl.17.5.427

25. Podsiadlo D, Richardson S. "The timed "Up \& Go": a test of basic functional mobility for frail elderly persons. J Am Geriatric Soc. 1991 Feb;39(2):142-8. https://doi.org/10.1111/j.1532-5415.1991.tb01616.x

26. Steffen T, Seney M. Test-retest reliability and minimal detectable change on balance and ambulation tests, the 36-item short-form health survey, and the Unified Parkinson Disease Rating Scale in people with parkinsonism. Phys Ther. 2008 Jun;88(6):733-46. https:// doi.org/10.2522/ptj.20070214

27. Siciliano M, Trojano L, Santangelo G, De Micco R, Tedeschi G, Tessitore A. Fatigue in Parkinson's disease: a systematic review and meta-analysis. Mov Disord. 2018 Nov;33(11):1712-23. https://doi. org/10.1002/mds.27461

28. Santos PCR, Gobbi LTB, Orcioli-Silva D, Simieli L, van Dieen JH, Barbieri FA. Effects of leg muscle fatigue on gait in patients with Parkinson's disease and controls with high and low levels of daily physical activity. Gait Posture. 2016 Jun;47:86-91. https://doi. org/10.1016/j.gaitpost.2016.04.002

29. Solla P, Cannas A, Mulas CS, Perra S, Corono A, Bassareo PP, et al. Association between fatigue and other motor and nonmotor symptoms in Parkinson's disease patients. J Neurol. 2014 Feb;261(2):382-91. https://doi.org/10.1007/s00415-013-7207-5

30. Mak MK, Pang MY. Balance confidence and functional mobility are independently associated with falls in people with Parkinson's disease. J Neurol. 2009 May;256(5):742-49. https://doi.org/10.1007/ s00415-009-5007-8

31. Paker N, Bugdayci D, Goksenoglu G, Demircioğlu DT, Kesiktas N, Ince N. Gait speed and related factors in Parkinson's disease. J Phys Ther Sci. 2015 Dec;27(12):3675-79. https://doi.org/10.1589/jpts.27.3675

32. Tan D, Danoudis M, McGinley J, Morris ME. Relationships between motor aspects of gait impairments and activity limitations in people with Parkinson's disease: a systematic review. Parkinsonism Relat Disord. 2012 Feb;18(2):117-24. https://doi.org/10.1016/j. parkreldis.2011.07.014

33. Valet M, Lejeune T, Glibert Y, Hakizimana JC, Van Pesch V, El Sankari $\mathrm{S}$, et al. Fatigue and physical fitness of mildly disabled persons with multiple sclerosis: a cross-sectional study. Int J Rehabil Res 2017 Sep;40(3):268-74. https://doi.org/10.1097/MRR.0000000000000238

34. Hoang CL, Salle JY, Mandigout S, Hamonet J, Macian-Montoro F, Daviet JC. Physical factors associated with fatigue after stroke: an exploratory study. Top Stroke Rehabil. 2012 Sep-Oct;19(5):369-76. https://doi.org/10.1310/tsr1905-369

35. Simonsick EM, Chia CW, Mammen JS, Egan JM, Ferrucci L. Free thyroxine and functional mobility, fitness, and fatigue in euthyroid older men and women in the Baltimore Longitudinal Study of aging. J Gerontol A Biol Sci Med Sci. 2016 Jul;71(7):961-7. https://doi. org/10.1093/gerona/glv226

36. Vestergaard S, Nayfield SG, Patel KV, Eldadah B, Cesari M, Ferrucci $L$, et al. Fatigue in a representative population of older persons and its association with functional impairment, functional limitation, and disability. J Gerontol A Biol Sci Med Sci. 2009;64(1):76-82. https://doi. org/10.1093/gerona/gln017 